\title{
Memahami Konsep Menyangkal Diri, Memikul Salib dan Mengikut Yesus: Sebuah Analisis Biblikal Lukas 9:23-26
}

\author{
Danny Yonathan \\ Sekolah Tinggi Teologi Berita Hidup \\ yonathandanny1@gmail.com
}

\begin{abstract}
From every generation, believers receive instruction that aims to strengthen faith and educate believers to become militant disciples of Christ, and have readiness to serve God in accordance with the true concept of Christian thought. Thus believers must dare to deny themselves, and carry the cross every day and follow Jesus Christ who is the Lord and Savior. This article had purpose to give the understanding biblically the concept of self-denying, carrying cross and following Jesus according to the text of Luke 9:23-26.
\end{abstract}

Keywords: cross carrying, following Jesus, self-denied

\begin{abstract}
Abstrak: Dari setiap generasi, orang percaya menerima pengajaran yang bertujuan untuk meneguhkan iman serta mendidik orang-orang percaya untuk menjadi murid Kristus yang militan, serta memiliki kesiapan untuk melayani Tuhan sesuai dengan konsep pemikiran Kristen yang benar. Orang percaya harus mau menyangkal diri, dan memikul salib setiap hari serta mengikut Yesus Kristus yang adalah Tuhan dan Juruselamat. Artikel ini bertujuan untuk memberikan pemahaman secara biblikal konsep menyangkal diri, memikul salib dan mengikut Yesus sesuai dengan teks pada Lukas 9:23-26.
\end{abstract}

Kata Kunci: menyangkal diri, memikul salib, mengikut Yesus

\section{PENDAHULUAN}

Di dalam sejarah tercatat secara jelas bahwa kekristenan selalu mengalami penindasan, penganiayaan, bahkan bukan hanya harga diri, materi duniawi saja melainkan nyawa juga dikorbankan, ada banyak orang-orang percaya yang mati demi Injil Kristus. Namun pada realita yang sering kali terjadi saat ini, orang-orang percaya justru lebih memilih menyangkal imannya kepada Yesus demi mendapatkan sesuatu yang diinginkan (kedudukan, jabatan, harta, penerimaan, pasangan hidup) dibanding harus hidup dalam penyangkalan diri dihadapan Tuhan. Andar mengemukakan bahwa: "Yesus adalah Allah yang bersimpati dan solider dengan penderitaan manusia, orang yang diperhitugkan sebagai anggota kerajaan Allah adalah orang yang merasa dirinya tidak mempunyai prestasi apa-apa dihadapan Allah tetapi mau mengikuti Dia dengan jujur dan setia dalam iman", dari pernyataan ini mengindikasikan bahwa iman menjadi dasar bagi seseorang untuk mampu memikul salib Kristus dengan setia

\footnotetext{
${ }^{1}$ Andar Ismail, selamat Mengikut Dia, (Jakarta: BPK Gunung Mulia, 2000), hlm. 82
} 


\section{Menyangkal Diri}

Dalam pengertian bahasa aslinya menyangkal diri memiliki pengertian: harus menolak, menyangkal, tidak mengindahkan, tidak berbohong, sedangkan kata diri merupakan kata ganti (kepemilikan) artinya " diri sendiri. ${ }^{2}$ kata menyangkal diri dalam luk 9:23 merupakan bebtuk kata perintah yang sanggat penting sekali, dan harus dilakukan. Bila diterjemahkan dalam Kamus besar Bahasa Indonesia memiliki pengertian: membantah, tidak mau menuruti. tidak membenarkan diri sendiri."3 Seperti yang telah ditulis dalam Injil Lukas 9: 23 bahwa "setiap orang yang mau mengikuti Aku, ia harus menyangkal dirinya..." Charles F. Pfeiffer menafsirkan kata menyangkal diri sebagai berikut: menyangkal artinya sama dengan yang dilakukan oleh Petrus pada saat Yesus diadili, dia menolak mengakui bahwa dia mengenal Yesus. ${ }^{4}$ Ini artinya untuk mengikut Yesus, untuk menjadi orang yang percaya kepada Yesus itu tidaklah mudah. Seseorang harus keluar dari situasi kenyamanan, mengabaikan kepentingan-kepentingan pribadinya dan ia harus menyangkal dirinya, demi untuk memberikan tempat yang utama bagi Tuhan. Memfokuskan diri (tubuh, jiwa dan roh) untuk memprioritaskan Yesus Kristus dalam hidupnya.

B. J Boland mengemukakan:

Menyangkal diri, tidak hanya dilakukan satu kali saja tetapi berkali-kali. Menyangkal diri artinya ia tidak boleh hidup menurut kemauannya sendiri atau begitu saja mewujudkan keinginannya sendiri, tetapi harus setiap hari belajar mendoakan "kehendak-Mu jadilah" seperti yang dilakukan oleh Tuhan Yesus sendiri (bnd 22: $42)^{5}$

Dalam mengikut Yesus tentunya ada banyak tantangan, kesulitan, terlebih dalam hal pengendalian diri sendiri dengan kata lain Kristus yang memimpin diri kita untuk berjalan dalam kehendak Allah, supaya dapat menanggung penderitaan dan penolakan yang pasti akan di alami baik secara langsung atau secara tidak langsung, itu sebabnya harus siap sedia dan berjaga-jaga. kita dapat menanggungnya, karena Yesus yang menjadi sentral hudup kita sebagai orang-orang yang percaya akan kuasa dan kebangkitan Kristus yang adalah Tuhan dan juruslamat.

Menyangkal diri dalam King James Version “let him deny himself” yang berarti (dia membiarkan, meniadakan, menyangkal dirinya sendiri) Sedangkan dalam New International Version menggunakan kata "he must deny himself "artinya ( keharusan untuk meniadakan diri sendiri ${ }^{\text {“6 }}$ kata ini memiliki atri yang sangat dalam bahwa setiap orang yang mau menjadi murud Kristus ia harus siap menyangkal diri, yang berarti membiarkan, meniadakan, dan bahkan menjadi suatu keharusan yang penting untuk

\footnotetext{
${ }^{2}$ Bible works, Version 7.0.

${ }^{3}$ Kamus Besar Bahasa Indonesia :Elektronik.

${ }^{4}$ Charles F. Pfeiffer, The Wycliffe Bible Commentary: Tarsiran Alkitab Wycliffe, Perjanjian Baru, Volume 3, (Malang: Yayasan Penerbit Gandum Mas, 2001)

${ }^{5}$ B . J . Boland, Tafsiran Kitab Lukas, (Jakarta: BPK Gunung Mulia, 1969), hlm. 201-202

${ }^{6}$ The Iversen - Norman Associates, Eight Translation New Testament: King James Version, liveng Bible, (New York, 1974), hlm. 478-479
} 
dilakukan yaitu meniadakan kepentingan diri sendiri dan mengutamakan kepentingan di dalam Kristus. Perkataan ini sesungguhnya perkataan yang sangat keras dalam atri perkataan ini merupakan perintah yang harus dikerjakan, karena perintah yang sangat penting bagi murid-murid Yesus dan semua orang yang percaya kepada Dia harus melakukanya. Hilda Pelawi mengemukakan bahwa: menyangkal diri bererti tidak mengutamakan dirinya sendiri, melainkan memberikan tempat yang utama hanya bagi Allah, manusia akan dapat menyangkal dirinya apabila ia berdamai dengan Allah, maka ia dapat berkata great is thy faithfulness o Lord my God dengan menyadari tentang kasih setia Allah yang besar maka penyangkalan diri akan menjadi pilihan terbaik yang di realisasikan dalam kehidupan oleh iman ${ }^{7}$

Dari pernyataan ini ternyata menyangkal diri merupakan pilihan oleh karena menyangkal diri tidaklah mudah dan tidak semua orang mau melakukannya, pada dasarnya semua orang dapat memilih untuk menentukan sikap hidupnya dihadapan Tuhan. Dalam hal ini Gert Behanna menegaskan bahwa: Apakah yang saya pilih dan lakukan ini tepat? Jika untuk Tuhan saya akan lakukan jika untuk diri sendiri saya tidak akan melakukannya, inilah sikap dan tindakan nyata dari seorang yang menyangkal diri, bersedia mengosongkan diri untuk kehendak dan kepentingan diri sendiri dan terfokus pada kehendak Allah ${ }^{8}$

Jelas bahwa motivasi untuk melakukan segala sesuatu perlu diuji, demikian halnya dengan menyangkal diri. Selanjutnya Budisatyo Tanihardjo menjelaskan bahwa "saat kita menyadari sepenuhnya bahwa segala sesuatu adalah dari Dia, oleh Dia kepada Dia maka kita tidak akan mudah tergoda oleh hal-hal yang bersifat ego sentris atau berpusat pada diri sendiri, dan hanya memuliakan nama Tuhan Yesus Kristus." ${ }^{9}$ Sebagai seorang murid kita harus dapat mengorbankan segala-galanya demi Kristus. Baik pengorbanan secara fisik untuk terus ikut Dia dan melayani Dia, pengorbanan waktu dan tenaga untuk terus dekat dengan Dia, bahkan pengorbanan materi untuk pekerjaan dan pelayanan-Nya di dunia ini. Pada dasarnya semua orang selalu memperlakukan diri sendiri sebagai yang paling penting dan utama dalam dunia ini, jikalau kita mau mengikut Yesus maka sudah menjadi ketetapan yang mutlak bahwa ia harus lebih mengutamakan Yesus di banding kepentingan, kehendak dari diri sendiri.

Dengan kesediaan menanggalkan segala keinginan, bukan berarti kemanusiaan kita hilang. Kita tetap sadar keadaan dan status kita dan kita tetap manusia dengan segala unsur kemanusiaan yang utuh. Menyangkal diri adalah suatu sikap dari ketetapan hati yang mengasihi Allah. Sikap yang barani berkata "tidak" terhadap dosa dan segala kehendak atau kesenangan yang bertentangan dengan kehendak Tuhan dan berkata "ya" untuk melakukan kehendak Allah. Proses penyangkalan diri melibatkan Allah dan diri kita secara

\footnotetext{
${ }^{7}$ Hilda Pelawi, Serpihan Cinta: Menemukan Tuhan Dalam Penderitaan, (Jakarta: BPK Gunung Mulia, 2013), 27

${ }^{8}$ Fred Smith SR, Memimpin dengan Integritas, (Jakarta: Yayasan Pekabaran Injil Imanuel, 2002), 20

${ }^{9}$ Budisatyo Tanihardjo, Integritas Seorang Gembala Sidang: Seorang Gembala Sidang dan Keberhasilan Pelayanan Di Gereja Lokal (Malang: Gandum Mas, 2009), 26
} 
utuh, untuk itu Roh kudus yang ada didalam hati kita membimbing pada kebenaran, memberi pengertian akan Firman Allah (Yoh 16:13; Ef 3:16-17). Dengan demikian dapat dipahami bahwa orang yang menyangkal diri adalah orang yang rela melepaskan (meniadakan) keinginannya sendiri dan larut dalam ketaatan pada apapun yang di inginkan oleh Tuhan Yesus. Jiwanya menjadi bejana dimana kehendak Tuhan di curahkan dalam jiwanya, sehingga pikiran dan perasaannya dikuasai oleh Yesus Kristus. Seperti Yesus telah mengosongkan diri-Nya mengambil rupa sebagai seorang hamba (Fil 2:7) maka pengikutnya (murid-mirid-Nya) harus siap untuk meneladani Dia dan mengosongkan diri dan menjadi seorang hamba yang setia ke pada Allah. Richard Clinton menulis mengenai menyangkal diri sebagai berikut:

Hubungan dengan Tuhan adalah merupakan fondasi untuk lebih dekat dengan Allah, keteguhan dalam menyangkal diri merupakan hasil dari sebuah hubungan yang penuh kepercayaan dengan Tuhan, mengakui kekuasaan Tuhan dan memiliki kesadaran yang penuh atas dirinya sehingga tidak menjadi angkuh, serta memiliki integritas serta menjadi serupa dengan Kristus. ${ }^{10}$

Sesungguhnya sudah seharusnya hidup orang-orang percaya menjadi sebuah ekspresi murni dari apa yang dipercayai tidak peduli bagai mana situasi dan apa konsekuensinya. Kehidupan seorang yang telah menyangkal diri di hadapan Allah seharusnya murni dalam mempercayai Tuhan di atas segala-galanya. Calvin Miller mencatat tentang menyangkal diri sebagai berikut: "Menyangkal diri memiliki arti melepaskan sifat cinta terhadap diri sendiri yang merupakan tabiat lama, dengan demikian kita juga akan lebih mudah meninggalkan perkara-perkara kecil lainnya."11 Orang yang menyangkal dirinya ia tidak akan berani mencintai dirinya melebihi cinta kasihnya kepada Allah. Dengan kata lain kasihnya ke pada Tuhan jauh lebih besar bila dibandingkan dengan kasih terhadap diri sendiri, hal ini dapat terlihat secara jelas dalam persekutuannya dengan Kristus. Ajith Fernando menjelaskan bahwa: Menyangkal diri itu menyerahkan diri dan membiarkan Kristus menjadi Tuhan atas hidup kita, karena Kristus tidak akan membinasakan diri yang berserah kepada-Nya. Tetapi ialah supaya kita bersekutu dengan Dia dalam ketundukan penuh terhadap Tuhan, tidak sonbong, angkuh atau tamak, melainkan mentaati kehendak Allah dan membiarkan kuasa Kristus memenuhi diri kita, sehingga Tuhan semakin besar dan kita semakin kecil, karena menyangkal diri yang sesungguhnya ialah membuang egosentris dan tabiat lama dari diri kita. “12

Penjelasan di atas menjadi bahan efaluasi bagi setiap pengikut Yesus, apakah sudah memberikan diri untuk dipimpin oleh Kristus atau mesih berkeras hati dan berusaha memimpin diri sendiri, mengutamakan Tuhan atau mengutamakan kehendak pribadi. Orang percaya yang sesungguhnya ialah mereka yang memuliakan Allah di dalam diri mereka tiap- tiaphari.

\footnotetext{
${ }^{10}$ Richard Clinton \& Paul Leavenworth, Memulai Dengan Baik, (Jakarta: Metanoia, CRM Empowering Leaders Worldwide, 2004), 69-70

${ }^{11}$ Calvin Miller, Pola Hidup Kristen, (Malang: Gandum Mas, 1997), 49

${ }^{12}$ Ajith Fernando, Hidup Yang Diserahkan, (Surabaya: Yakin, 2001),. 216-217
} 
Dari berbagai pedapat yang telah diperoleh penulis dapat memahami bahwa semua orang yang telah mengambil keputusan untuk membuka hati, menerima Tuhan Yesus sebagai Tuhan dan juruslamat secara pribadi dalam hidupnya serta berkomitmen untuk mengikut Yesus dengan sungguh-sungguh ia juga harus memiliki kesiapan hati untuk menyangkal diri. Yang berarti tidak mengutamakan kepentingan diri sendiri, tetapi mengutamakan Kristus yang adalah pemimpin yang hakiki atas hidupnya serta tidak sombong, angkuh dan tamak, melainkan dengan kerendahan hati dan diri untuk senantiasa hidup menyatu dengan Kristus dalam persekutuan dan senantiasa tunduk serta taah untuk melakukan kehendak Tuhan dalam hidupnya, dengan demikian Tuhan semakin besar dan kita semakin kecil dengan demikian Tuhan di permuliakan dan setiap orang percaya diberkati. Hanya kedasaran yang utuh tentang kasih karunia Tuhan saja yang dapat memampukan orang-orang percaya dapat secara jujur hidup dalam penyangkalan diri yang berintegritas dan berkualitas tinggi sebagai murid Kristus. Dengan demikian pada pembahasan selanjutnya penulis akan membahas tentang bagaimana cirri-ciri orang percaya yang menyangkal diri di hadapan Tuhan.

\section{Ciri-ciri Orang Yang Menyangkal Diri}

Dalam Lukas 9: 23-24, dimana kepentingan atau kehendak pribadi tidak lagi menjadi hal yang diutamakan dalam hidupnya, Menurut Henry $\mathrm{C}$ Thiessen mengemukakan bahwa "kita (orang percaya), memuliakan Dia dengan kehidupan yang saleh""13 dengan demikian tidak lagi mengikuti kehendaknya sendiri (segala keinginan dan seluruh hawanafsu) tetapi lebih cenderung melakukan segala sesuatu yang menjadi kehendak Tuhan dalam kehidupannya, yaitu mengikuti Dia dan memuliakan Dia dengan hidup kudus dan berkenan dihadapan Allah (di dalam Kristus). Untuk memahami bagian ini penulis akan memaparkannya dalam beberapa poin penting diantaranya:

\section{Memprioritaskan Yesus dalam Hidupnya}

Tidak dapat disangkal bahwa Tuhan menghendaki murid-murid-Nya rela melepaskan apapun yang menjadi kesukaan, kebanggaannya yang bertentangan dengan Firman Tuhan, demi melakukan kendah Tuhan karena Tuhan berhak menerina yang terbaik, sebagai contoh ialah tindakan Abraham yang memtaati Allah dan melakukan perintah Allah dengan ketundukan sekalipun itu bertentangan dengan hatinya sebagai seorang bapa, (Kej 22: 1-3; Yoh 8:39). Tuhan menghendaki kehidupan orang percaya seperti Abraham. Jika sesorang mengutamakan Tuhan dalam segala hal, maka apapun yang dimiliki, sudah pasti akan di pakai hanya untuk hormat dan kemuliaan bagi nama Tuhan. Sehingga kita menjadi semakin rendah, dan Tuhan-lah yang ditinggikan di dalam hidup kita, dan ini gambaran dari orang yang hidup dalam kerendahan hati di dalam Tuhan Yesus dan memprioritaskan Tuhan Yesus di atas segala-galanya dalam hidup. Markus mencatat "Karena siapa yang mau menyelamatkan nyawanya, ia akan kehilangan nyawanya; tetapi barangsiapa kehilangan nyawanya karena Aku dan karena Injil, ia akan menyelamatkan nyawanya"

\footnotetext{
${ }^{13}$ Henry C. Thiessen, Teologi sistematika, (Malang: Gandum Mas 2000), 509
} 
(Mar. 8:35) yang dimaksudkan adalah, orang-orang yang lebih memilih untuk menikmati hidup di dunia ini dengan segala kesenangannya. Orang-orang yang sama sekali tidak tertarik untuk memikirkan perkara-perkara yang diatas atau semua hal tentang langit baru dan bumi yang baru. Bagi orang percaya yang mau mengutamakan Tuhan diatas segalagalanya, maka ia akan rela kehilangan nyawanya karena kebenaran injil Kristus, tetapi dibalik semuanya itu ia akan menuai keindahan hidup kekal di dalam Kerajaan Allah Bapa di sorga.

\section{Tidak Menyayangkan Nyawanya bagi Yesus}

Pentingnya kepercayaan bahwa jika kita kehilangan nyawa karena Kristus dalam iman, kita menyelamatkannya dengan mendatangkan keuntungan yang tak terkatakan yaitu hidup dalam kekekalan. Mengapa Tuhan Yesus memberi syarat kepada pengikut-Nya untuk tidak menyayangkan nyawanya, kalau mereka mau menjadi pengikut yang benar luk 9:23. Kata nyawa dalam bahasa aslinya menggunakan kata (Psykhen) yang juga dapat disebut "Jiwa" yang mengandung pikiran, perasaan dan kehendak. Dr. Erastus mengungkapkan bahwa "dalam jiwa manusia ada keinginaan-keinginan dan hasrat, di dalam jiwa ada berbagai pengertian dan fiolosofi oleh sebab itu seorang yang rela kehilangan nyawa harus rela merubah filosofi hidupnya". ${ }^{14}$ Perubahan ini bias terjadi bila jika mengalami pembaharuan pikiran di dalam Kristus.

Perubahan yang signifikan ditandai dengan kerelaan berkorban (mengorbankan apapun) demi melakukan kehendak Allah dan menyelesaikan pekerjaan-Nya sebagai seorang murid yang mau taat dan setia ke pada Yesus. Seorang yang siap kehilangan nyawanya adalah orang yang benar-benar rela menjadi seperti anggur yang tercurah dan roti yang terpecah, merekalah yang tidak menyayangkan nyawanya seperti majikan agungnya yaitu Tuhan Yesus Kristus yang adalah anak Allah". ${ }^{15}$ Orang-orang percaya yang seperti ini sesungguhnya ia telah meneladani sikap hidup Tuhan Yesus dalam hal menyangkal diri dihadapan Tuhan Allah. Yohanes mencatat dalam Why 12:11 "dan mereka telah mengalahkan dia oleh darah anak Domba, dan oleh perkataan kesaksian mereka, karena mereka tidak mengasihi nyawa_mereka sampai kedalam maut" kata mengalahkan "dia" yang di maksudkan ialah "Iblis yang mendakwa" mereka siang dan malam di hadapan Allah (Ay 10). ${ }^{16}$ Orang-orang yang dapat mengalahkan Iblis adalah mereka yang benar-benar telah mengalami suatu perjuangan Iman yang sungguh-sungguh sampai tidak menyayangkan nyawanya sendiri dan menyerahkan hidupnya hanya bagi Kristus.

Dalam hal ini seorang tersebut tidak memiliki kesenangan atau keinginan kecuali melakukan kehendak Bapa. Perjuangan yang sedemikian rupa juga telah di alami oleh Rasul Paulus "darahnya siap dicurahkan demi pelayanan bagi jemaat Tuhan 2 Tim 4:6-8"

\footnotetext{
${ }^{14}$ Erastus Sabdono, Menemukan Kekristenan yang Hilang, (Jakarta: Rehobot Literatur- Rehobot Ministry, 2015), hlm. 65

${ }^{15}$ Ibbid.., hlm. 65-66

${ }^{16}$ Lembaga Alkitab Indonesia: Wahyu, (Yayasan Lembaga Alkiab Indonesia, 2008), 302
} 
dan inilah standar murid Kristus yang militan "rela melepaskan nyawa bagi saudarasaudaranya I Yoh 3:16".Jadi sesungguhnya kehidupan di dunia bukan untuk bersenangsenang sendiri (memuaskan hawa nafsu dan keinginan-keinginan diri sendiri), melainkan untuk bekerja menggenapi rencana Allah. Memegang tongkat estafet pelayanan yang berpusat pada pengharapan dan penyelamatan yang telah diselesaikan Yesus di atas kayu Salib.

Pada dasarnya segala sesuatu yang ada di dalam dunia ini pasti akan lenyap dan binasa, dunia hancur sebagai akibat dosa, akan tetapi Jiwa/ Roh tidak akan pernah binasa, itu sebabnya tidak perlu kita menyayangkan nyawa kita untuk mengikut Yesus, karena jika kita mencintai nyawa kita lebih dari cinta kita kepada Tuhan sesungguhnya kita telah kehilangan jiwa yang hidup. Tetapi setiap orang yang tidak menyayangkan nyawanya bagi Tuhan maka jiwanya senantiasa akan terpelihara di dalam Kristus, itu sebabnya tepat pada waktunya akan memperoleh jiwa yang mengalami hidup kekal bersama Kristus yang adalah sumber kehidupan. Hidup baru di dalam Kristus seperti yang ditulis oleh Paulus di dalam "Rom 6:1-23" yaitu mati bagi dosa dan bangkit dalam Kristus. YM Imanuel Sukardi berpendapat bahwa: Mati bagi dosa, bukan berarti orang percaya tidak dapat berbuat dosa lagi, melainkan orang percaya sudah tidak hidup di dalam dosa. Harus dibedakan antara tidak hidup dalam dosa lagi dengan tidak bias berbuat dosa lagi. Jadi orang percaya bukan tidak bisa berbuat dosa lagi melainkan tidak lagi hidup di dalamnya. ${ }^{17}$

Penulis sangat setuju dengan pernyataan tersebut, karena sebagai orang yang telah di satukan dengan kematian dan kebangkitan Kristus, maka harus hidup baru di dalam Kristus bukan dalam dosa. Sehingga hidup baru telah mematikan keinginan hidup dalam dosa (Rom 6: 7-11). Manusia lama kita telah turut disalibkan, seperti yang di katakana oleh Tuhan Yesus dalam Luk 9: 22-26, tujuannya supaya tubuh dosa itu hilang kuasanya dan tidak menghambakan atau mengapdikan diri terhadap dosa tetapi supaya serupa dengan kemuliaan dan kebangkitan Kristus."18 Apa gunanya seorang memperoleh seluruh Dunia tetapi ia membinasakan atau merugikan dirinya sendiri (Luk. 9:25). Dengan demikian sangat penting bagi orang percaya untuk menyatu dengan Kristus agar tidak hidup di bawah kuasa dosa. Karya Kristus dalam kaitannya dengan pemberesan dosa telah selesai, maut tidak berkuasa lagi atas Dia demikian juga dengan orang percaya yang telah disatukan dengan Dia, telah memperoleh hidup baru yaitu hidup baru bagi Allah.

Dalam Luk 9: 26 "Sebab barang siapa malu karena Aku dank arena perkataan $\mathrm{Ku}$ maka Anak manusia juga akan malu karena orang itu..." J.L Ch. Abineno mengemukakan "mengaku (hamologein) lebih tertuju kedalam, artinya mengakui di hadapan orang banyak Rom 10:9"19 Sebelum Tuhan Yesus naik ke Surga Ia telah memberikan perintah kepada para murid-murid-Nya "pergilah jadikanlah semua bangsa murid $\mathrm{Ku}$ dan babtislah mereka dalam nama Bapa dan Anak dan Roh Kudus Mat 28:19-20” ini merupakan perintah yang

${ }^{17}$ YM Imanuel Sukardi Th. M, Holy Bible: Berkat-berkat Surat Roma, (Surakarta: STT Berita Hidup, 2011), 98

${ }^{18}$ Ibid .., 100

${ }^{19}$ J.L Ch. Abineno, Jemaat, (Jakarta: BPK Gunung Mulia, 1987), 25 
di terima oleh para murid pada waktu itu dan juga kepada kita sekarang ini yang disebut sebagai Amanat Aggung Tuhan Yesus. Untuk merealisasikan kerajaan Allah di dalam muka bumi ini tidaklah mudah. Jika ke -12 rasul mereka telah berkorban bagi Kristus di dalam melayani dan mewartakan kabar baik hal itu menunjukkan bahwa kematian di dalam Kristus bukan suatu kebetulan tetapi mereka harus berkorban bagi Kristus untuk melayani Allah. Seperti ungkapan yang pernah diungapkan oleh Tertulianus demikian "Darah kaum martir adalah benih Gereja". Dalam hal ini penulis menyetujui pernyataan ini, bahwa dalam pemberitaan Injil ada banyak bahkan sangat banyak hamba-hamba Tuhan, misiyonaris yang mati, di bunuh karena Injil. Tetapi sebagai orang percaya tidak perlu takut karena setiap orang yang kehilangan nyawanya karena Yesus ia menyelamatkan nyawanya (Luk 9: 24b).

\section{Mengikut Yesus sebagai Seorang Murid}

Mengikut Yesus sebagai seorang murid, berarti mengikuti jalan-Nya, mentaati perintahnya, melakukan titahnya sebagai tugas dan tanggung jawabnya, serta tidak malu menyatakan otoritas Tuhan Yesus sebagai Tuhan dan penebus dosa semua umat manusia. Dalam Luk 9: 26, "sebab barang siapa malu karena Aku dan karena perkataan $\mathrm{Ku}$, Anak manusia juga akan malu mengakui orang itu apa bila Ia datang kelak dalam kemuliaan Bapadan malaikat-malaikat kudus." Malu karena Yesus berarti merasa malu atau rikuh di hadapan dunia pada saat kita menyatukan diri dengan jalan, nilai dan sasaran hidup yang Yesus ajarkan.Malu karena Yesus adalah merasa malu karena Firman-Nya, malu untuk mengakui bahwa Firman itu sepenuhnya diilhami oleh Allah, malu untuk hidup taat kepadanya dan mempertahankannya. Orang seperti itu akan ditolak dan dihukum oleh Kristus Mat 10:33." ${ }^{20}$ secara teologis, Lukas 9:23-26, menjelakan bahwa orang yang mengikut Yesus akan mengalami tantangan hidup yaitu banyaknya penderitaan, penolakan dan bahkan dibunuh. Sebagai bukti biblika terdapat dalam Injil Matius 5:10-12 ketika Yesus khotbah di bukit "berbahagialah orang yang dianiaya karena kebenaran, karena mereka yang empunya kerajaan sorga. Bahkan difitnahkan segala yang jahat..."21 tetapi orang-orang percaya haedaknya member kesaksian hidup yang nyata agar Injil Kristus di beritakan dan nama Tuhan dipermuliakan.

\section{Arti Memikul Salib}

Menerima Yesus sebagai Tuhan dan juruslamat tidak hanya menuntut percaya akan kebenaran Injil, tetapi juga menyerahkan diri untuk mengikuti Dia dengan pengorbanan (Mrk 8:34). Seperti yang telah disebutkan pada pembahasan latar belakang penulisan karya Ilmiah ini, bahwa keselamatan dari Tuhan adalah kasih karunia Allah yang diberikan kepada umat manusia yang mau percaya kepada-Nya (Rom 3:24), tetapi untuk menjadi murid atau pengikut Yesus harus melewati berbagai proses diantaranya ialah memikul salip Kristus setiap hari (Luk 9:23). Jika kita mencermati ayat ini mungkin yang terlintas

\footnotetext{
Jam 16:03.

${ }^{20}$ http://alkitab.sabda.org/commentary.php?book 42\&chapter-9\&verse-26 Di akses tgl 7 Juni 2016

${ }^{21}$ Lembaga Alkitab Indonesia, Perjanjian batu- New Testament, (LAI, 1993), 9-10
} 
dalam benak kita adalah penderitaan. Memikul salib adalah bagian dari paket penyaliban yang harus dijalani oleh seorang yang menerima hukuman salib. Kata memikul dalam bahasa aslinya menggunakan kata " $\alpha \rho \alpha$. Tindakan untuk memikul salib tidak hanya di lakukan satu kali saja, tetapi di lakukan secara berulang-ulang (terus menerus secara sederhana dapat diartikan setiap hari). Sedangkan kata Salib dalam bahasa yunaninya (stauron) merupakan kata benda yang berarti kayu salib, dua belah kayu yang besiang. Dalam bahasa latin memiliki beberapa pengertian yang cukup menarik diantaranya adalah :crus,; cruciego.Atrinya yang pertama ialah, kayu yang didirikan tegak.Kedua kayu slaan sebagai alat untuk menghukum dan menghukum mati seseorang. Dalam PB kata salib dalam bentuk kata benda muncul 28 kali dan kata kerjanya 46 kali. oleh sebab itu salib identik dengan penderitaan, kesakitan dan pergumulan yang berat."22

Tuhan Yesus juga mengalami hal yang demikian, Ia harus menanggung penderitaan dan menempuh jalan Salib sebagai konsekuensi sebagai hukuman yang di akibatkan oleh dosa manusia. Yesus harus menanggung beratnya kayu salib, muka dan tubuh-Nya berdarah-darah karena berkali-kali Ia terjatuh ketanah dan terhempas di berbatuan cadas, badan-Nya hancur, tercabik-cabik oleh tajamnya cambuk yang mengoyak daging-Nya. Ia juga menanggung malu karena ditonton orang banyak sebagai seorang hukuman. kata salib ditulis secara berulang-ulang hal ini menunjukkan bahwa persoalan memikul salib merupakan persoalan yang serius dan menuntut tanggung jawab. Dalam kehidupan kekristenan saat ini apakah orang-orang percaya siap memikul salib setiap hari seperti yang telah di alami dan dilakukan oleh Tuhan Yesus.

Dalam catatan sejarah seseorang dipaku di atas kayu salib darahnya akan mengalir setetes demi setetes, jantungnya berdetak lebih kencang sampai berakhir pada kematian. ${ }^{23}$ Kristus menyatakan kasih Allah, hanya saliblah tempat di mana tidak ada kasih sama sekali, salib adalah ruang hampa dari kasih murid-murid yang mengasihi Yesus dan selalu berada di sekeliling-Nya kasih mereka pun juga tidak dapat Yesus terima karena Yesus harus menebus dosa mereka. Dengan demikian maka jelaslah bahwa pada dasarnya bukan orang-orang percaya yang mengasihi dan berkorban bagi Yesus melainkan Yesus yang mengasihi dan berkorban bagi orang-orang percaya.

Apakah orang-orang percaya siap memikul salib Kristus setiap hari? Dan bagaimana pengertian memikul salib yang benar berdasarkan teks Luk 9:23. Mungkin yang kita ketahui hanya sepersepuluh, seperseratus atau bahkan sepersejuta, tetapi puji Tuhan karena Dia tidak mau kita tidak mengetahui apa-apa tentang sengsara dan salib-Nya.Orang yang mengenal kesengsaraan Kristus adalah orang yang bisa mencintai Tuhan. Kita tidak mencintai Tuhan karena kita tidak sadar akan kasih Tuhan tetapi kita mencintai Tuhan karena kita sadar dan mengerti secara benar tentang kasih sebagai bentuk karunia Allah dan penganpunan dosa manusia. Sebagai contoh rasul Yohanes memberitakan kasih Allah Karena Yohanes adalah rasul yang berada di bawah salib. Karena pengenalan akan salib

\footnotetext{
${ }^{22}$ Segenap penyusun, Ensiklopedi jilid ke II,(Jakarta :yayasan komunikasi bina kasih OMF, 2013), 341

${ }^{23}$ Ibbid ,. 3
} 
dan sengsara Yesus Kristus mengakibatkan seseorang masuk ke dalam tempat Mahakudus dari kasih Tuhan Allah. Choan- Seng Song juga menjelaskan bahwa: Penderitaan adalah tempat manusia dan Allah bertemu, baik pembesar maupun orang-orang kecil, orang saleh maupun orang-orang besdosa. Penderitaanlah yang membuat manusia dekat dengan Allah. Yesus bukan hanya juruslamat bagi orang-orang bedosa tetapi juga juruslamat orang-orang asing, yang dimaksud sebagai orang-orang asing ialah orang-orang bukan yahudi. ${ }^{24}$

Penjelasan di atas merupakan penekanan yang penting bagi para murid, bahwa Tuhan Yesus adalah Tuhan dan juruslamat semua orang yang memperdamaikan, mempertemukan mereka dengan Allah. Charles F. Pfeiffer menafsirkan kata memikul salib sebagai berikut : memikul salib-Nya setiap hari artinya secara sukarela menerima segala tanggung jawab dan penderitaannya yang ada kaitannya dengan menjadi murid Krustus. ${ }^{25}$ Manusia tidak perlu putus asa lagi, tidak perlu kecewa lagi, karena Allah Tuhan Pencipta kita sudah menjalankan mujizat untuk menggenapi apa yang telah dijanjikan-Nya kepada manusia yang murtad kepada Allah saat manusia jatuh kedalam dosa dengan penuh tanggung jawab. Ivan Haryanto menulis tentang orang percaya yang tangguh dan memikul Salib sebagai berikut: Seseorang yang memikul salib Kristus ialah seorang yang memilih untuk menderita sampai mati dari pada menyangkal Kristus atau karya-Nya; yang mengorbankan sesuatu yang sangat penting untuk melebarkan kerajaan Allah, dan yang bertahan dalam penderitaan yang hebat karena menjadi saksi Kristus. ${ }^{26}$

Dengan demikian dapat dipahami bahwa sudah merupakan suatu tindakan yang mutlak bagi semua orang yang mengikut Yesus, untuk siap mengambil, mengangkat dan membawa serta salib Kristus dalam kehidupan tiap-tiap hari sebagai reaksi iman secara aktif karena telah menjadi murid Yesus yang taat dan setia kepada Tuhan Allah serta rela menderita sebagai saksi Kristus. Matius mencatat "pikullah kuk yang Ku pasang dan belajarlah kepada $\mathrm{Ku}$, karena Aku lemah lembut dan rendah hati dan jiwamu akan mendapat ketenangan" (Mat. 11: 29). Hanya dengan berpusat kepada Yesus maka para murid-Nya pun akan dimampukan untuk memikul salib serta kuk yang telah di kehendaki oleh Allah untuk di pukulnya secara aktif tiap-tiap hari. Fengky M., S.E, menulis tentang derita dan perjuangan seorang tokoh reformasi dalam memikul Salib Kristus sebagai berikut: Martin Luther seorang tokoh yang hebat, mengalami banyak penderitaan, dan berbagai kejadian yang melemahkan semangatnya dan untuk kembali menyatakan kebenaran Kristus Ia membayar harga, memikul salib secara rohani yang Allah kehendaki untuk menjadi bagiannya, ia di pandang sebagai seorang pemberontak bahkan penyesat sehingga ia di usir bahkan ada usaha untuk membunuhnya, akan tetapi penyertaan Tuhan tidak diragukan lagi. Memikul salib berarti siap berjalan dalam kebenaran Kristus sekalipun sulit, rela menerima penderitaan yang disebabkan oleh kebenaran Kristus, berani

\footnotetext{
${ }^{24}$ Choan- Seng Song, The Compassionate God, (Maryknoll: Orbis Books, 1982), 41,44

${ }^{25}$ Charles F. Pfeiffer, Volume 3.

${ }^{26}$ Ivan Haryanto, Batu-Batu Tersembunyi: Dalam Pondasi Kita, (Surabaya: KDP Indonesia, 2000), 13
} 
menyatakan kebenaran sekalipun sukar dan siap berkorban bagi Tuhan Yesus berdasarkan ketundukan terhadap kehendak Allah",27

Leon Morris juga menjelaskan makna salib sebagai berikut:

Salib Kristus adalah jalan perdamaian (Propitiation) berarti berbalik dari kemarahan, dengan jalan salib Kristus menanggung murka Allah yang mengerikan akibat dosa manusi, melalui salib Kristus ada pendamaian (Rekonciliation) artinya penyelesaian sesuadah pertengkaran atau perseteruan Rom 5:10 akar penyebabnya adalah Dosa, dalam Kristus menusia tidak lagi berseteru dengan Allah, melainkan ada pendamaian, penyelesaian yang tuntas sehingga relasi manusia dengan Allah mengalami pemulihan,melalui salib ada pembenaran (Jutstification) adalah suatu konsep hukum, yaitu segala tuntutan hokum terhadap orang-orang berdosa yang berada di dalam Kristus seluruhnya di penuhi oleh kematian-Nya disalib. ${ }^{28}$

Salib dapat dilihat dari berbagai segi, akan tetapi pada bagian ini salib Kristus tidak hanya dipandang sebagai penderitaan, pergumulan dan kematian, tetapi di dalam salib juga memiliki makna perdamaian, pendamaian dan pembenaran yang dikerjakan oleh Kristus bagi semua orang yang percaya dan yang hidup di dalam Dia.

\section{Tujuan Memikul Salib}

Dalam segala perbuatan yang di kerjakan pasti memiliki tujuan yang pasti menjadi titik fikus. Pada bagian ini penulis akan membahas tentang tujuan orang percaya dalam memikul salib Kristus ialah: Untuk Mengikut Yesus, artinya untuk menunjukkan kemurnian hati dan kepercayaan yang utuk Kristus yang adalah Tuhan dan pemimpin yang memiliki otoritas tertinggi dalam hidup dan pribadinya. selanjutnya meneladani Yesus, sebagaimana Yesus Kristus adalah prototype awal yang harus di teladani oleh orang-orang percaya maka sebagai mana Kristus hidup demikian orang percaya hidup, sekalipun penulis juga menyadari bahwa kita tidak dapat sempurna seperti Kristus, akan tetapi Kristus akan menolong kita untuk menjadi serupa dengan Dia dan bersatu dengan Dia dalam melaksanakan misi Allah di dalam dunia ini. Dan yang terakhir tujuan memikul salib adalah untuk berkorban bagi Yesus karena Dia telah terlebih dulu berkorban bagi orang-orang yang percaya (dunia). Salib akan mebawa manusia dalam kesadaran yang utuh, membuat orang percaya teberani berkorban bagi Kristus, teguh dalam iman, pengharapan dan kasih serta memiliki ketundukan yang penuh terhadap kehendak Allah.

Yesus yang adalah Allah rela mengambil rupa seorang hamba dan menjadi sama dengan manusia. Perlu dicatat bahwa pada masa pemerintahan Romawi, hamba adalah pribadi yang dianggap rendah, tidak bernilai.Hamba dapat diperlakukan sewenang-wenang oleh majikannya.Dari sini kita mengetahui pengorbanan sejati yang dilakukan oleh Yesus Kristus bagi seluruh umat manusia." 29 Seluruh pengorbanan dan pelayanan Yesus di dunia ini diarahkan pada satu tujuan yang jelas, yaitu Bapa dimuliakan dan genaplah janji Bapa

\footnotetext{
${ }^{27}$ Fengky M. Masalah Adalah Berkat, (Jakarta: Indonesia Galilea Ministri, 2004), 91

${ }^{28}$ Leon Morris, Salib Yesus, (Malang: Wm. B. Eerdmans Publishing, 1994) ,. 7-10.

${ }^{29} \mathrm{http}$ ///www.glorianet.org/manati/994-pengorbanan, tanggal 7, Juni, jam 21.30
} 
tentang karya keselamatan bagi dunia ini, dan kiranya tujuan Allah juda dapat kita pahami sehingga Tuhan dipermuliakan di dalam seluruh eksistensi diri dan kehidupan orang-orang percaya.

\section{Arti Mengikut Yesus}

Keputusan untuk mengikut Yesus bukanlah hal yang mudah tetapi ada harga yang harus dibayar. Tuhan Yesus berkata kepada setiap orang "setiap orang yang mau mengikut $\mathrm{Aku}$, ia harus menyangkal dirinya, memikul salibnya setiap hari dan mengikut Aku" (Luk 9:23-26). Perkataan Tuhan Yesus tentang "mengikut Aku" ini di sampaikan secara terus menerus, baik secara lisan pada waktu itu dan secara tulisan baik pada waktu Tuhan Yesus mengajar pada waktu itu sampai pada zaman kita saat ini, tulisan (Firman Allah) yang di tujukan kepada seluruh orang-orang percaya. Douglas mengemukakan bahwa: kita harus tahu bahwa Yesus tidak pernah bermaksud membuat manusia lebih baik, tetapi Ia hidup utuk membuat manusia yang baru, semua ajaran Yesus tidak akan pernah cocok bagi manusia yang masih terikat dengan belenggu dosa, karena Yesus membebaskan manusia dari dosa. ${ }^{30}$

Dari penjelasan di atas maka dapat dipahami bahwa setiap orang yang ingin mengikut Yesus harus meninggalkan cara hidupnya yang lama dan menghidupi manusia baru di dalam Yesus Kristus. Charles F. Pfeiffer menafsirkan kata mengikut dan menyangkal sebagai berikut: Kata Yunani mengikut adalah (akoloutheite) artinya suatu perintah yang memerlukan tiddakan yang tak putus-putus "hendaklah ia terus mengikut Aku dengan menjadi murid Kristus. ${ }^{31}$ Tetapi para murid pada waktu itu mereka tidak mengetahui bahwa akhir dari perjalanan-Nya berakhir di salib, karena mereka masih berpikir tentang penaklukan dan kuasa (22:24) sehingga pernyataan ini merupakan hak yang sangat penting bagi para murid untuk mengevaluasi ulang harga yang harus dibayar untuk menjadi murid Kristus.kata "aku” (menujuk pada pribadi Tuhan Yesus).

Dengan kata ini memiliki arti "setiap orang ingin mengikuti Yesus. NET (New English Transation) "mengikut Aku" adalah anyone wantsto become my follower, yang artinya "siapapun yang ingin menjadi pengikut $\mathrm{ku}$ " KJV: if any man will come after me, artinya "siapa saja orang yang ingin datang mengikut Aku"sedangkan dalam bahasa Ibdonesia kata mengikut memiliki arti "turut, menyertai, berjalan bersama" 32 hal ini menunjukkan bahwa Tuhan Yesus menyampaikan perkataan ini secara berulang-ulang, dan adanya hubungan yang dekat dan erat, perkataan Tuhan Yesus tidak hanya di tujukan kepada ke-12 Muridnya saja tetapi kepada siapa saja (semua orang) yang mau meresponi panggilan Allah, Setiap orang yang mau mengikut Yesus sebaiknya memiliki pertobatan yang sungguh-sungguh, dan senantiasa memiliki kerinduan untuk selalu hidup berkenan kepada Allah dengan menjari serupa dengan Kristus.

${ }^{30}$ Douglas D. Webster, kehidupan Kristen dalam kebudayaan duniawi, (Malang: Gandum Mas,1980), 29-28

${ }_{31}^{31}$ Charles F. Pfeiffer, Perjanjian Baru, Volume 3.

${ }^{32}$ Bible works 7 , 
Chris Marantika mengemukakan bahwa: Mengikut Yesus adalah bersekutu dengan Dia, dan persekutuan dengan Tuhan Allah itu bersifat kasih, dan kudus artinya Tuhan ingin membangun persekutuan yang bersih dari segala kenajisan. Kejahatan, dan dosa. Karen Allah adalah kudus dan kita harus hidup kudus. Komitmen mengikut Yesus, yaitu tekat yang bulat untuk mengikut Yesus dan melayani-Nya itu menuntut pengorbanan yang sangat mahal harganya dan tekad untuk tetap mengikut dia apapun yang terjadi. Dalam hal seorang hamba Tuhan yang bernama William Carey dengan berbagai macam resiko yang berat, anak-anaknya harus mati karena sakit, istrinya menjadi gila. Akan tetapi ia tahu bahwa Allah yang memanggil dia dan ia setia dengan panggilan Tuhan itu ia tetap mengikut Yesus, kekristenan tidak terlepas dari kesaksian hidup, itu sebabnya orang-orang percaya harus dapat memberikan kesaksian yang baik dan benar di tengah-tengah masyarakat yang pluralis keyakinanya.

Kesaksian yang hidup adalah prilaku yang mencerminkan karakteristik Kristus ${ }^{\text {"33 }}$ mengikuti Dia, bersama-sama dengan Dia dan menyatu dengan Dia. Menurut Sinclair Fergusson berpendapat bahwa "Ungkapan yang sering dipakai oleh Paulus untuk menyebut persatuan dengan Kristus ialah "dalam Kristus, dalam Dia, dan dalam Tuhan"34 jadi tidak hanya datang, sekedar ingin mengikuti Yesus tetapi mau hidup di dalam Dia dan menjalani hidup dalam kekudusan Allah. Karena persekutuan adalah kesatuan Kristus dengan umatNya hal ini terlihat jelas dalam tindakan Yesus untuk menebus dosa umat-Nya. Ungkapan ini pada hakekatnya sama dengan ungkapan Paulus dalam Gal 2:19 "aku telah di salibkan dengan Kristus". Itu sebabnya untuk mengikut Yesus dibutuhkan iman yang sejati. Richard mengemukakan bahwa: "kerinduan untuk mengikut Yesus ditanam di dalam hati kita oleh Allah sendiri tetapi kita harus bertindak menurut panggilan itu jadi mengikut Yesus adalah soal menanggapi Dia pada waktu Ia memanggil kita dan dari hari kehari kita terus mengikut Dia"35

Orang yang menaruh kepercayaannya ke pada Tuhan tidak akan mudah goyah, imannya tidak akan mudah lemah, dan pengharapannya tidak akan hilang serta kasih dan pengorbanan menjadi ucapan syukur dalam mengikut Tuhan Yesus. Dngan demikian tidak ada ruang keraguan dalam mengiku Yesus, sehingga dalam segala keadaan baik suka, duka, penderitaan bahkan kematian sekalipun tidak adan dapat melenyapkan iman kepercayaan terhadap Kristus, seperti yang diungkapkan Paulus dalam Rom 8:35-37.

Dari penjelasan di atas maka penulis menemukan arti yang dapat di pahami secara jelas tentang kata "Mengikut Aku". Kata ini tidak hanya di ucapkan satu kali saja, serta tidak berarti sekedar datang, mengikuti Yesus, tetapi bagaimana orang-orang percaya (pengikut Kristus) itu turut serta dan tinggal di dalam Kristus (menyatu) dengan Kristus dan tetap mengikuti Dia secara aktif (terus menerus) tidak boleh berhenti untuk tetap mengikuti Dia. Dalam Alkitab Edisi Study menjelaskan “dalam perjalanan-Nya ke

\footnotetext{
${ }^{33}$ Chris Marantika, Roti yang mengenyangkan Jiwa, (Yogyakarta: STII Prees, 2005), hlm. 119

${ }^{34}$ Sinclair B. Fergusson, TheChristian Life: A Diktrinal Introduktion (Edinburgh, Scotland : The Banner Of Truth Trust, 1989), hlm. 104

${ }^{35}$ Richard Halverson, mengenal Kristus, (Surabaya: Yakin, 1987),hlm. 191
} 
Yerusalem, Yesus berjumpa dengan banyak orang. Ada yang memahami ajaran-Nya dan memutuskan utuk mengikuti-Nya, tetapi ada juga yang tidak memahami atau tidak bersedia melakukan apa yang menjadi tuntutan bagi seorang pengikut Yesus"36 dengan kata lain tidak semua orang dapat meresponi perintah Tuhan secara benar, kendatipun demikian bagian ini memberi penegasan penting bagi orang percaya sebagai pengikut Yesus yang setia, yaitu sekali percaya Yesus maka selamanya akan tetep perbaya Yesus, sekali mengikut, Yesus selamanya akan mengikut Yesus, sekali mengambil keputusan untuk percaya Yesus, maka selamanya akan tetap berdiri di atas dasar iman kepada Yesus apapun yang terjadi di dalam kehidupannya.

\section{Konsekuensi Mengikut Yesus}

Dalam hal mengikut Tuhan Yesus bukanlah hal yang mudah, tetapi penuh dengan tantangan dan kesulitan. Firman Tuhan berkata "setiap orang yang mau mengikut Aku ia harus menyangkal dirinya, memikul salibnya setiap hari dan mengikut Aku" (Luk 9: 23) dan setiap orang percaya yang mengikut Yesus pasti akan mengalaminya. G. w. Bromiley menjelaskan "penderitaan atau pemaksaan mental, moral atau fisik, yang mana orang yang berkuasa baik indifidu maupun khalayak ramai/ orang banyak membebankannya kepada orang lain"37 secara teologis, Lukas 9:23-26, menjelakan bahwa orang yang mengikut Yesus akan mengalami tantangan hidup yaitu banyaknya penderitaan, penolakan dan bahkan dibunuh. Sebagai bukti biblika terdapat dalam Injil Matius 5:10-12 ketika Yesus khotbah di bukit "berbahagialah orang yang dianiaya karena kebenaran, karena mereka yang empunya kerajaan sorga.

Janji Tuhan yang sangat luar biasa ialah ketika orang percaya harus menderita karena nama Yesus maka maka orang tersebut akan mengalami kebahagiaan dari Tuhan. Sebagai contoh 1 Petrus 4:14 "Berbahagialah kamu, jika kamu dinista karena nama Kristus, sebab Roh kemuliaan, yaitu Roh Allah ada padamu”. Tuhan Yesus juga berkata dalam Yoh 15:20 "ingatlah apa yang Ku katakana kepada mu: seorang hamba tidaklah lebih tinggi dari pada tuannya. Jikalau mereka telah menganiaya Aku, mereka juga akan menganiaya kamu; jikalau mereka telah menuruti Firman Ku, mereka juga akan menuruti perkataan mu", oleh karena itu penganiayaan boleh terjadi karena "penganiayaan adalah satu tanda seorang kepada Tuhan dimana Tuhan akan memberkati "siapa saja yang dianiaya karena kebenaran"38

\section{Tindakan Yang Dilakukan Untuk Mengikut Yesus}

Sesuai dengan pengertian yang telah dipaparkan diatas maka, penulis menelaah tindakan yangharus dilakukan dalam mengiring atau mengikut Yesus ialah menjadi seorang murid-Nya yang meresponi suara Tuhan dengan baik dan benar serta melakukan

\footnotetext{
${ }^{36}$ Segenap penyusun, Alitab Edisi Studi, (Jakarta: Lembaga Alkitab Indonesia LAI, 2014), 1685

${ }^{37}$ G. W. Bromiley, The International Standard Bible Ensyclopedia, (Grand Rapids, Michigan: Willam B. Eerdmans Publishing Company, 1986), 771

${ }^{38}$ G. Ebel, Colin Brown, Lother Coenen, dkk, The New International Diktionary Of New Testament teoligy (Grand Rapid, Michigan: Zonder Publishing House, 1976 ), 806
} 
segala sesuatu yang Ia kehendaki di dalam kehidupannya. B.J Boland dalam bukunya yang berjudul Inti Sari iman Kristen mengemukakan bahwa "mengikut Tuhan dengan meneruh kepercayaan sepenuhnya kepada Dia" ${ }^{39}$ Penting agar kita hidup menurut kehendak Tuhan dan meneladani Dia sehingga dapat menjadi seorang murid yang serupa dengan Yesus bukan menjadi serupa dengan dunia (Rom. 12:2). Iman dan kasih kepada Tuhan tidak dapat bertumbuh jika kita tidak lebih banyak belajar mengenal Dia. Proses pembelajaran menjadi murid Yesus tidak terjadi secara otomatis dengan bertambahnya usia. Untuk menjadi seorang murid yang dewasa secara rohani dibutuhkan kerelaan untuk melatih diri dalam hal-hal rohani.JR W Stott dalam bukunya hidup sebagai Kristen mengungkapkan bahwa: Orang-orang percaya zaman ini adalah orang yang sibuk dengan segala macam urusan, tetapi bagaimana segala kepentingan dan urusan kita kita harus mampu mengaturnya sedemikian rupa sehingga ada waktu khusus untuk bertemu dengan Tuhan Allah bergaul dengan Dia muka dengan muka ${ }^{40}$

Dalam hal ini penulis juga dapat memahami tindakan yang harus di lakukan oleh murid-murid Yesus yang militan diantaranya ialah, terus melatih diri untuk hidup dalam persekutuan dengan Tuhan, memiliki kerendahan hati dan penyangkalan diri di hadapan Kristus serta berani menbayar harga seperti, memikul salib dengan rela dan tulus hati, dengan kata lain menyalibkan segala keinginan daging dan seluruh hawa nafsunya Rom 6:6 "karena kita tahu, bahwa manusia lama kita telah turut disalibkan, supaya tubuh dosa kita hilang kuasanya agar jangan kita menghambakan diri lagi kepada dosa”. Karena dosa tidak memiliki kuasa atas kehidupan orang-orang percaya. Rasul Paulus mencatat bahwa: Karena kamu telah mendengar tentang Dia dan menerima pengajaran di dalam Dia menurut kebenaran yang nyata di dalam Yesus, yaitu bahwa kamu, berhubung dengan kehidupan kamu yang dahulu, harus menanggalkan manusia lama yang menemui kebinasaannya oleh nafsunya yang menyesatkan, supaya kamu dibaharui di dalam Roh dan pikiranmu dan mengenakan manusia baru, yang telah diciptakan menurut kehendak Allah di dalam kebenaran dan kekudusan yang sesungguhnya.

Jadi setiap orang yang telah percaya dan menjadi pengikut Yesus ia harus mengambil tindakan yang serius untuk meninggalkan kehidupan lama yang penuh dengan dosa dan hidup baru bersama dengan kebenaran yang terdapat dalam Yesus. Herman Ridderbos mengemukakan bahwa " salah satu pengaruh dari pemulihan kehidupan manusia adalah peniadaan dosa dalam diri manusia yang telah percaya kepada yesus dan mengalami kemerdekaan Kristen" 41 dari penjelasan di atas maka penulis dapat menyimpulkan bahwa, tindakan orang percaya dalam hal mengikut Yesus adalah berani mengabaikan kepentingan diri sendiri dan mengutamakan kehendak Tuhan Yesus, hidup dalam kekudusan dan tidak kompromi dengan dosa sebagai reaksi Iman dan ketaatannya kepada Tuhan Yesus.

\footnotetext{
${ }^{39}$ B.j Boland, Inti Sari Iman Kristen, (Jakarta: BPK Gunung Mulia, 1993), 15

${ }^{40}$ JR W Stott, Hidup Sebagai Kristen, (Jakarta: BPK Gunung Mulia, 1983), 21

${ }^{41}$ Herman Ridderbos, Paulus: Pikiran Utama Teologi Paulus, (Surabaya: Momentum, 2008), 213
} 


\section{KESIMPULAN}

Dalam kehidupan menjadi murid Yesus harus menyangkal dirinya, artinya tidak lagi memngutamakan kepentingan diri sendiri dibandingkan kepentingan pelayanan untuk Tuhan Yesus. Tidak egois, tidak memposisikan kepentingan pribadi lebih tinggi dari kehendak Allah. Melainkan hidup dalam ketundukan terhadap kehendak Tuhan secara total dan setia mengikut Dia. Dalam kehidupan menjadi murid Yesus, harus berani menanggung penderitaan seperti yang dialami Tuhan Yesus, Ia menderita karena kehendak Allah Bapa, bukan karena dosa atau kesalahan-Nya. Kristus adalah prototipe yang sempurna untuk diteladani dalam segala hal termasuk dalam menanggung penderitaan. Walaupun setiap orang tidak sama tingkat kesulitan atau penderitaan hidupnya. Menderita yang dimaksudkan ialah: menderita karena kebenaran yang terdapat dalam Kristus, karena mengikut Yesus dengan taat dan setia dan bukan karena kesalahan atau kejahatannya sendiri. Dalam kehidupan menjadi murid Yesus harus memiliki perubahan hidup dan pola pikir yang di perbaharui, untuk memprioritaskan Tuhan dalam kehidupan tiap-tiap hari dan menjalani kehidupan sebagai pengikut Yesus atau sebagai seorang murid yang setia, dan harus berani berkata ya untuk Yesus dan tidak untuk yang lain (sekali mengikut Yesus maka selamanya akan tetap mengikut Yesus)

\section{REFERENSI}

Abineno, Jemaat, Jakarta: BPK Gunung Mulia, 1987.

B.j Boland, Inti Sari Iman Kristen, Jakarta: BPK Gunung Mulia, 1993.

Bible works 7 ,

Bible works, Version 7.0.

Boland B . J ., Tafsiran Kitab Lukas, Jakarta: BPK Gunung Mulia, 1969.

Choan- Seng Song, The Compassionate God, Maryknoll: Orbis Books, 1982.

Fengky M. Masalah Adalah Berkat,Jakarta: Indonesia Galilea Ministri, 2004.

Fergusson, Sinclair B., TheChristian Life: A Diktrinal Introduktion. Edinburgh, Scotland :

The Banner Of Truth Trust, 1989.

Fernando, Ajith, Hidup Yang Diserahkan,Surabaya: Yakin, 2001.

Fintawati Rahardjo \& Ivan Haryanto, Devosi Total: Kisah-kisah Pengorbanan Sehari-hari Orang-orang Percaya dari Masa kuno Hingga Masa modrn Yang Mengorbankan Segalanya Demi Kristus,Surabaya: KDP, 2005.

G. Ebel, Colin Brown, Lother Coenen, dkk, The New International Diktionary Of New Testament teoligy. Grand Rapid, Michigan: Zonder Publishing House, 1976.

G. W. Bromiley, The International Standard Bible Ensyclopedia,Grand Rapids, Michigan: Willam B. Eerdmans Publishing Company, 1986.

Graham, Billy, The Blly Graham Christian Worker's Handbook,Jakarta: Persekutuan Pembaca Alkitab, 1986.

Halverson, Richard, mengenal Kristus, Surabaya: Yakin, 1987.

Haryanto , Ivan, Batu-Batu Tersembunyi: Dalam Pondasi Kita, Surabaya: KDP Indonesia, 2000.

Ismail, Andar, selamat Mengikut Dia, Jakarta: BPK Gunung Mulia, 2000.

JR W Stott, Hidup Sebagai Kristen. Jakarta: BPK Gunung Mulia, 1983.

Kamus Besar Bahasa Indonesia :Elektronik.

Koyama,Kosuke, No Handle on The Croos,London, 1976. 
LAI, Perjanjian Baru- New Testament, 1993.

Lembaga Alkitab Indonesia, Perjanjian batu- New Testament,LAI, 1993.

Lembaga Alkitab Indonesia: Wahyu,Yayasan Lembaga Alkiab Indonesia, tahun anggaran 2008.

Marantika, Chris, Roti yang mengenyangkan Jiwa, Yogyakarta: STII Prees, 2005.

Miller, Calvin, Pola Hidup Kristen,Malang: Gandum Mas, 1997.

Morris, Leon Salib Yesus, Malang: Wm. B. Eerdmans Publishing, 1994.

Nahuway, Jacob, Jalan Kesorga Telah Rata, Jakarta: BPK Gunung Mulia, 1989.

Pelawi, Hilda, Serpihan Cinta: Menemukan Tuhan Dalam Penderitaan,Jakarta: BPK Gunung Mulia, 2013.

Pfeiffer, Charles F., The Wycliffe Bible Commentary: Tarsiran Alkitab Wycliffe,

Perjanjian Baru, Volume 3, .Malang: Yayasan Penerbit Gandum Mas, 2001.

Pfeiffer, Charles F., Perjanjian Baru, Volume 3.

Richard Clinton \& Paul Leavenworth, Memulai Dengan Baik,Jakarta: Metanoia, CRM Empowering Leaders Worldwide, 2004.

Ridderbos , Herman, Paulus: Pikiran Utama Teologi Paulus. Surabaya: Momentum, 2008.

Sabdono, Erastus, Menemukan Kekristenan yang Hilang, Jakarta: Rehobot LiteraturRehobot Ministry, 2015.

Segenap penyusun, Alitab Edisi Studi,Jakarta: Lembaga Alkitab Indonesia LAI, 2014.

Segenap penyusun, Ensiklopedi jilid ke II, Jakarta :yayasan komunikasi bina kasih OMF, 2013.

Smith SR, Fred, Memimpin dengan Integritas, Jakarta: Yayasan Pekabaran Injil Imanuel, 2002.

Sukardi, Imanuel, Holy Bible: Berkat-berkat Surat Roma,Surakarta: STT Berita Hidup, 2011.

Tanihardjo, Budisatyo, Integritas Seorang Gembala Sidang: Seorang Gembala Sidang dan Keberhasilan Pelayanan Di Gereja Lokal.Malang: Gandum Mas, 2009.

The Iversen - Norman Associates, Eight Translation New Testament: King James Version, liveng Bible,.New York, 1974.

Thiessen , Henry C., Teologi sistematika, Malang: Gandum Mas 2000.

Webster, Douglas D., kehidupan Kristen dalam kebudayaan duniawi, Malang: Gandum Mas, 1980.

Wiersbe, Warren W., Nyata di Dalam Kristus,Bandung: Kalam Hidup, 1972. 